\title{
Pelatihan Pembinaan Pengerajin Batik Di STT Real Batam
}

\author{
Clarins Claristha H.D. Simatupang ${ }^{*}$, Fredy Simanjuntak ${ }^{2}$, Ardianto Lahagu ${ }^{3}$, Adenia \\ Hotmayesi Sinaga ${ }^{4}$, Foera-era ndruru ${ }^{5}$, Ester Erlita silaban ${ }^{6}$, Yoeli Zai ${ }^{7}$, Rame Ima \\ $\operatorname{Irda}^{8}$ \\ 1,3, 6, 7,8 Prodi PAK, STT REAL Batam \\ $2,4,5$ Prodi Teologi, STT REAL Batam \\ * claristhaarine@gmail.com
}

\begin{abstract}
This study aims to determine the extent to which students view batik craftsmen at STT Real Batam. This research also provides an insight into the important role of students in preserving the cultural heritage of the Indonesian nation which must be preserved and preserved. By using the qualitative analysis method and collecting data based on literature review and questionnaires, data data will be formulated regarding the views of STT Real Batam students about written batik. Based on these results, it can be concluded that the students' view of batik craftsmen is that making batik takes a lot of time, can be done as a part-time, requires a large amount of capital, requires an artistic spirit, is more suitable for women and requires perseverance. With research, strategies can be formulated and things that must be improved for the development of extracurricular batik at STT Real Batam.

Keywords: Training, Coaching, Batik Craftsmen, STT Real Batam
\end{abstract}

\begin{abstract}
Abstrak
Penelitian ini bertujuan mengetahui sejauh mana pandangan para mahasiswa terhadap pengerajin batik di STT Real Batam. Penelitian ini juga memberikan pandangan akan peran penting mahasiswa dalam melestarikan warisan budaya bangsa Indonesia yang harus dilestarikan dan dijaga. Dengan mengunakan metode analisis kulitatif dan mengumpulkan data berdasarkan kajian pustaka dan kuisioner akan dirumuskan data data mengenai pandangan mahasiswa STT Real Batam tentang batik tulis. Berdasarkan hasil itu, dapat di simpulkan pandangan mahasiswa terhadap pengerajin batik bahwa membatik menghabiskan banyak waktu, dapat dilakukan sebagai sambilan, memerlukan modal yang besar, memerlukan jiwa seni, lebih cocok dilakukan oleh perempuan dan memerlukan ketekunan. Dengan penelitian dapat dirumuskan strategi dan halhal yang harus ditingkatkan untuk pengembangan ekstrakulikuler batik yang ada di STT Real Batam.

Kata Kunci: Pelatihan, Pembinaan, Pengerajin Batik, STT Real Batam
\end{abstract}

\section{PENDAHULUAN}

Batik adalah warisan budaya bangsa yang memiliki nilai seni yang tinggi. Batik tidak hanya di kenal dikalangan bangsa tetapi sudah terkenal di pasaran dunia. Memahami kebudayaan khususnya seni batik berarti memahami pula simbol-simbol, nilai-nilai, dan makna yang menjadi landasan bagi masyarakat pendukungnya. Dilihat dari perkembangan zaman,banyak generasi muda memiliki minat untuk mengunakan batik tetapi tidak dalam minaat untuk belajar dan menjadi pengerajin batik, khusunya batik tulis. Jika hal ini terus berlangsung maka sumberdaya manusia pengerajin batik akan mengalami kepunahan sehingga pelestarian warisan seni batik akan hilang dengan begitu saja.

Banyak cara yang dapat dilakukan untuk melestarikan warisan budaya yang adi luhung ini, yaitu diantaranya adalah membiasakan memakai baju batik, baik itu untuk sehari-hari maupun untuk acara resmi, dan mau belajar membatik, agar generasi pembuat batik profesional tetap lahir dibumi Indonesia ini. ${ }^{1}$ Di STT Real Batam sendiri telah membuka ekstrakulikuler batik tulis untuk mengembangkan budaya Indonesia dan menambah keahlian para mahasiswanya untuk berkreativitas dan berkarya dalam dunia seni. Dengan mengetahui pandangan dan alasan generasi muda terhadap pengerajin batik tulis di STT Real Batam ini maka dapat dirumuskan bagaimana strategi selanjutnya untuk mengembangkan batik tulis di STT Real Batam.

\footnotetext{
${ }^{1}$ Murni Marlina Simarmata, Mengenal Batik Nusantara (Jawa Timur: Lestari Kiranatama, 2014).49
} 


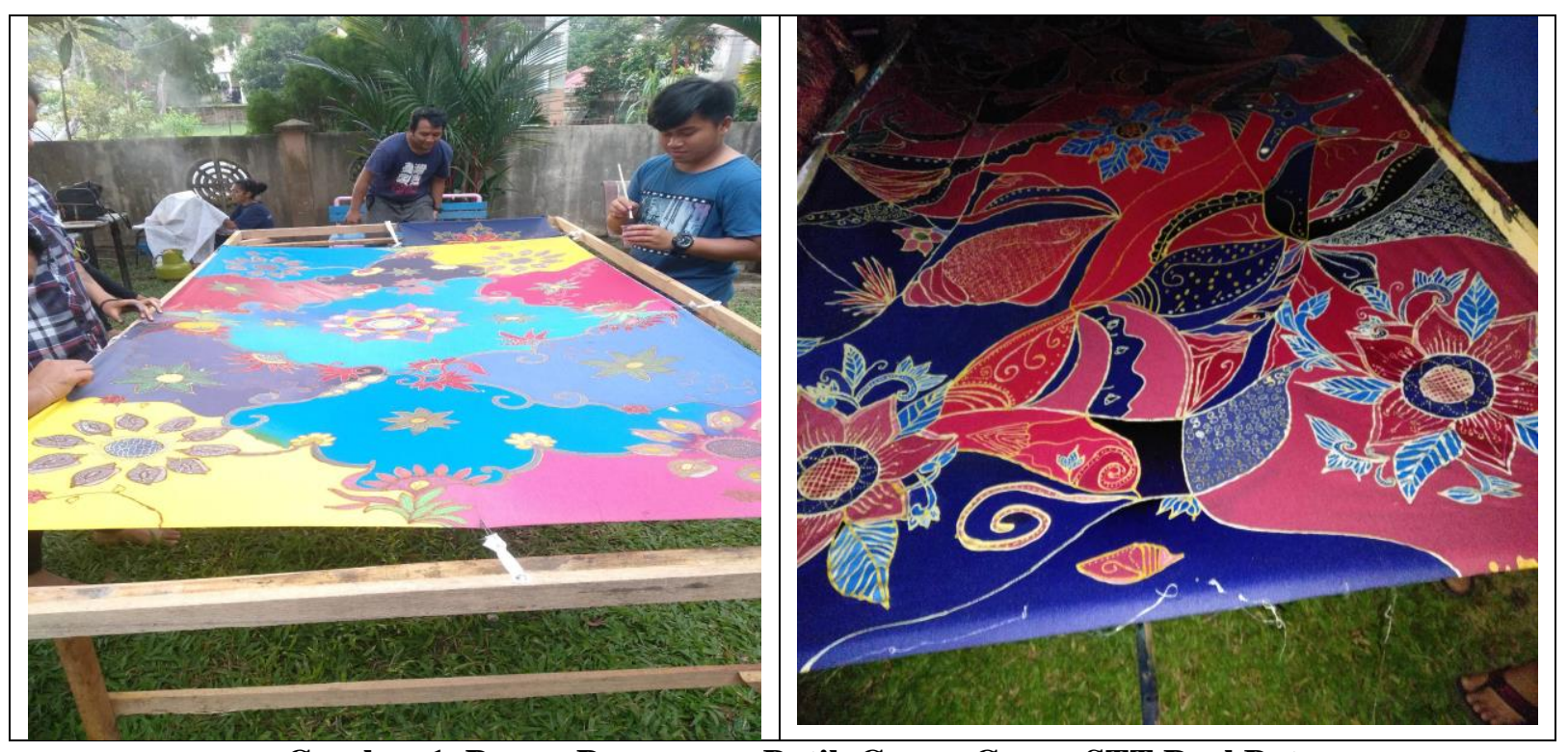

Gambar 1. Proses Pewarnaan Batik Goeng-Goeng STT Real Batam

\section{METODE}

Penelitian ini dilakukan oleh penulis dengan mengunakkan metode Deskripsi kualitatif dimana penelitian ini menganalisis data,mengumpulkan data, mengintpresi data dan merumuskan kesimpulan yang mengacu pada analisis data tersebut. Adapun tujuan dari penelitian ini adalah untuk mengungkapkan kejadian atau fakta, keadaan, fenomena, variabel dan keadaan yang terjadi saat penelitian berlangsung dengan menyuguhkan apa yang sebenarnya terjadi. Penelitian ini menafsirkan dan menguraikan data yang bersangkutan dengan situasi yang sedang terjadi, sikap serta pandangan yang terjadi di dalam suatu masyarakathubungan antar variable yang timbul, perbedaan antar fakta yang ada serta pengaruhnya terhadap suatu kondisi mengenai pandangan generasi muda terhadap profesi batik tulis di STT Real Batam. Selain dari metode di atas Penulis juga melakukan pendekatan lain dalam melakukan kegaitan PkM tersebut. Kegiatan pelatihan untuk pembinaan pengerajin batik yaitu para dosen dan mahasiswa STT Real Batam ini berlangsung dari 1 Mei 2018-2 Juni 2019. Kegiatan ini akhirnya menjadi salah satu kegiatan ekstrakurikuler bagi mahasiswa yang ingin mengembangkan ketrampilan membatik.

\section{HASIL DAN PEMBAHASAN Pandangan Generasi Muda}

Dalam hal ini pandangan generasi muda terbagi atas dua kata yaitu pandangan dan generasi muda. Dalam kamus besar bahasa Indonesia Pandangan diartikan dengan hasil perbuatan memandang (memperhatikan, melihat, dan sebagainya) contoh: 'laporan pandangan mata' atau pendapat (Kata kiasan) contoh: 'menurut pandangan saya, gagasan itu realistis'. Pandangan ini lah yang kemudian disebut dengan sebuah persepsi. Istilah persepsi ini juga diibaratkan sebagai gambaran atau anggapan dari seseorang. Menurut Slameto Definisi persepsi merupakan sebuah proses yang didalamnya menyangkut hal mengenai masuknya pesan ataupun informasi ke dalam otak. Melalui persepsi, maka manusia akan terus menerus berhubungan dengan lingkungannya. Hubungan yang dijalani ini dilakukan melalui indera yang dimiliki seperti penglihatan, peraba, perasa, pendengar, serta penciuman. Sedangkan menurut Thoha (1993) mengatakan bahwa persepsi pada hakekatnya adalah proses kongnitif yang dialami oleh setiap orang didalam memahami informasi tentang lingkungan, baik lewat penglihatan, pendengaran, penghayatan, perasaan,dan penciuman. ${ }^{2}$

${ }^{2}$ Siti Munawaroh, Peranan Kebudayaan Daerah Dalam Perwujudan Masyarakat Industri Pariwisata Di Daerah Istimewa Yogyakarta (Yogyakarta: Departement Pendidikan dan Kebudayaan, 1999).47 
Sedangkan definisi pemuda menurut Undang-Undang No. 40 tahun 2009 tentang Kepemudaan adalah warga negara Indonesia yang memasuki periode penting pertumbuhan dan perkembangan yang berusia 16 (enam belas) sampai 30 (tiga puluh) tahun. Dalam kosakata bahasa Indonesia, pemuda juga dikenal dengan sebutan generasi muda dan kaum muda. Berdasarkan definisi tersebut, maka dapat dijelaskan bahwa pemuda adalah individu yang sedang mengalami masa-masa perkembangan baik secara fisik maupun secara psikis. ${ }^{3}$

Berdasarkan defenisi pandangan dan generasi muda maka dapat dirumuskan definisi Pandangan generasi muda adalah sebuah proses kongnitif yang dialami oleh orang yang berusia enambelas sampai tigapuluh tahun didalam memahami informasi tentang lingkungan, baik lewat penglihatan, pendengaran, penghayatan, perasaan,dan penciuman.

\section{Batik Tulis}

Batik (atau kata batik) berasal dari bahasa Jawa "amba" yang berarti menulis dan "titik". Kata narik merujuk pada kain dengancorak yang dihasilkan oleh bahan "malam" yang diaplikasikan ke atas kain, sehingga menahan masuknya bahan pewarna. ${ }^{4}$

Berita baik mencapai puncaknya, saat UNESCO menyatakan batik Indonesia sebagai warisan budaya dunia tak benda, bersama 76 warisan budaya dunia tak benda lainnya. Pengakuan UNESCO berarti diwariskan dari generasi ke generasi, terus dicipta ulang dan memeknai identitas yang berkelanjutan. Pengakuan ini juga pada akhirnya menuntut pemerintah dan masyarakat untuk melakukan promosi, preservasi dan oroteksi. Dahulu batik dikenal sebagai sesuatu yang berat, atau kuno. Namun kini, batik dapat berkembang mengikuti selera konsumen yang lebih beragam. Dengan kekreatifan yang ada, kini batik tidak hanya digunakan sebagai kain atau sarung pandanan kebaya, atau pakaian, akan tetapi merambah jauh dalam dunia fasion manjadi tas, sandal, bahkan juga kalung. Batik sudah menjadi sebuah industri sejak 300 tahun yang lalu, sejak kain ini mulai diperdagangkan. Nilai ekonomi dal kelenturannya dalam menyikapi perkembangan jaman, membuatnya tetap bertahan. ${ }^{5}$

Dengan keunggulan yang dimiliki Indonesia terhadap batik, maka batik bisa menjadi salah satu potensi yang bisa dimanfaatkan masyarakat Indonesia untuk meningkatkan pendapatan ekonominya serta mengembangkan budaya yang ada di berbagai daerah. Potensi pengembangan batik sangat besar mengingat Indonesia memiliki banyak hal yang bisa dituangkan menjadi motif didalam kain batik.

Batik tulis adalah suatu teknik melukis diatas kain, dimana kain tersebut akan dihiasi dengan tekstur dan dan corak batik menggunakan tangan, yaitu digambar dengan pensil dan canting untuk menutupi atau pelindung terhadap zat warna. Batik tulis merupakan batik yang spesial dan mahal dibanding batik yang lain karena dalam pembuatan batik ini sangat diperlukan keahlian serta pengalaman, ketelitian kesabaran dan juga waktu yang lama untuk menyelesaikan sebuah batik tulis. Untuk sebuah batik tulis paling cepat dapat diselesaikan selama dua minggu oleh seorang pembatik, itupun dikarenakan cuaca yang cerah dan desain motif yang biasa dan tidak terlalu rumit. Pembuatan batik jenis ini memakan waktu kurang lebih 2-3 bulan. Adapun tahapan-tahapan dalam proses pembuatan batik ini:

a. Tahap pertama atau disebut juga proses pembatikan pertama, yaitu pembuatan pola dan motif yang dikehendaki diatas kain putih dilukis dengan pensil.

\footnotetext{
${ }^{3}$ Suliyanto Suliyanto, Weni Novandari, and Sri Murni Setyawati, "Persepsi Generasi Muda Terhadap Profesi Pengrajin Batik Tulis Di Perbalingga," Jurnal Ekonomi dan Bisnis 18, no. 1 (2015): 135-144.

${ }^{4}$ Deden Dedi S, Sejarah Batik Indonesi (Bandung: PT. Sarana Pancakarya Nusa, 2018).2

${ }^{5}$ Reni Kusumawdhani, How To Wear Batik (Jakarta: PT.Gramedia Pustaka Umum, n.d.).2
} 
b. Tahap kedua, melukis dengan lilin malam menggunakan canting dengan mengikuti pola tersebut pada kedua sisi.(bolak balik)

c. Tahap selanjutnya, menutuoi dengan dengan lilin malam bagian-bagian yang akan tetap berwarna putih.

d. Tahap berikutnya, proses pewarnaan pertama pada bagian yang tidak tertutup oleh lilin dengan mencelupkan kain tersebut pada warna tertentu

e. Setelah dicelupkan, kain tersebut dijemur dan di keringkan

f. Setelah kering, kembali melakukan proses pembatikan yaitu melukis dengan lilin malam mengunakan canting untuk bagian yang tetap ingin dipertahankan warna awalnya.

g. Kemudian dilanjutkan dengan proses pencelupan kedua

h. Proses berikutnya, menghilangkan lilin malam dari kain tersebut dengan cara meletakan kain tersebut dengan air panas diatas tungku atau kompor

i. Proses terakhir adalah mencuci kain batik tersebut dan kemudian mengeringkannya dengan menjemur kain tersebut. ${ }^{6}$

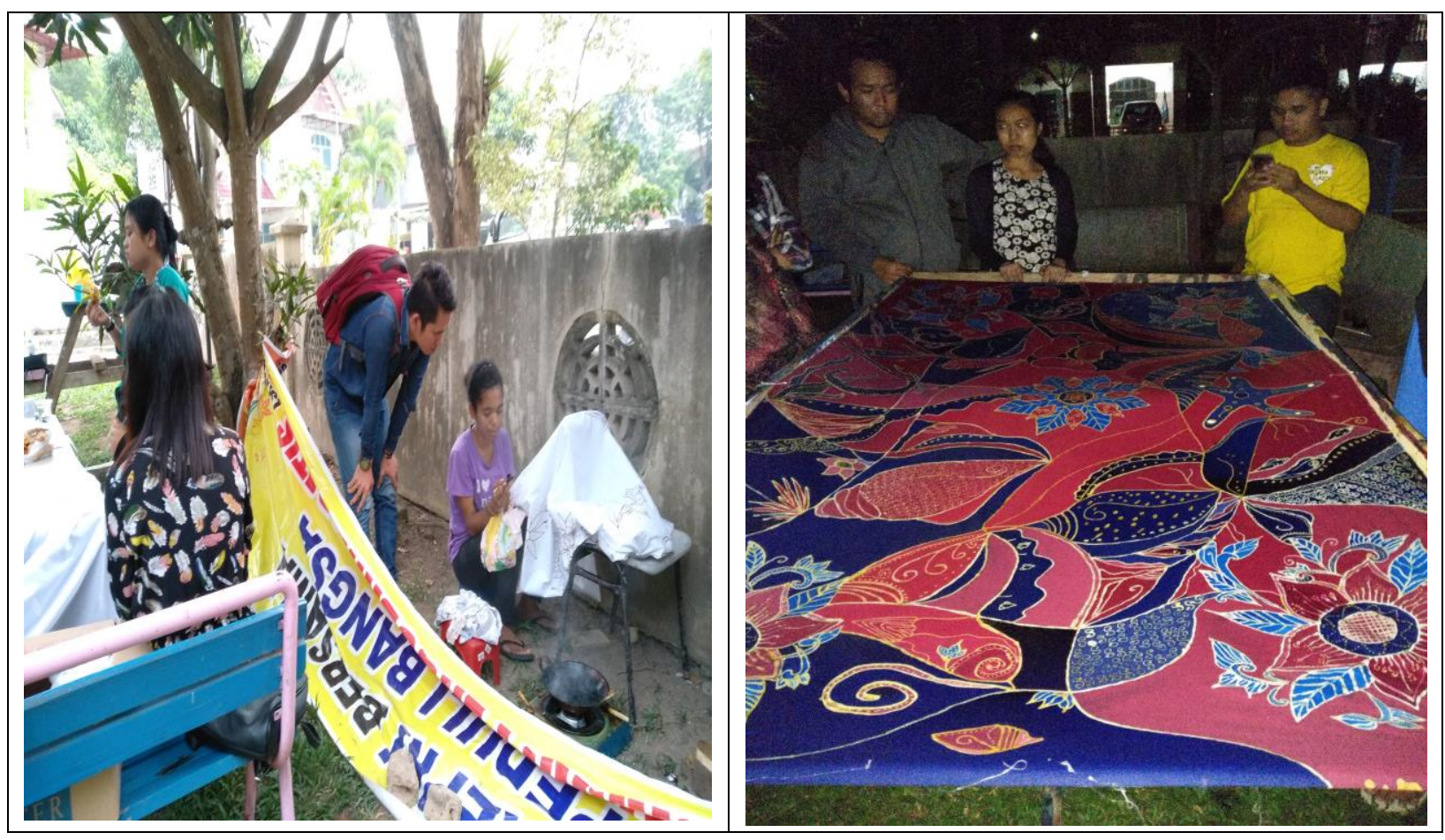

Gambar 2. Proses Awal \& Pewarnaan Pewarnaan Batik Goeng-Goeng STT Real Batam

\section{Instrumen Pengumpulan Data}

Analisis mengenai pandangan generasi muda terhadap pengerajin batik tulis di STT Real Batam dilakukan dengan menyebarkan angket kuisioner untuk mengetahui bagaimana pandangan mahasiswa STT Real. Penelitian di lakukan dengan menyebarkan angket kepada mahasiswa Di STT Real dengan jumlah responden 60 orang. Berdasarkan hasil pengumpulan data berupa kuisioner dapat diperoleh hasil sebagai berikut:

Tabel 1. Atribut untuk menyusun pandangan generasi muda mengenai pengerajin batik.

\begin{tabular}{|l|l|l|l|}
\hline No & \multicolumn{1}{|c|}{ Pertanyaan } & Ya & Tidak \\
\hline 1 & Pengerajin batik lebih cocok untuk perempuan? & 38 & 29 \\
\hline
\end{tabular}

\footnotetext{
${ }^{6}$ Rahmat Sunnara, Legenda Batik Tulis (Buana Cipta Pustaka, 2009).54
} 


\begin{tabular}{|l|l|l|l|}
\hline 2 & $\begin{array}{l}\text { Pengerajin batik tidak banyak tidak banyak menghasilkan } \\
\text { keuntungan? }\end{array}$ & 10 & 57 \\
\hline 3 & Membatik memerlukan ketekunan? & 67 & 0 \\
\hline 4 & Memerlukan jiwa seni? & 66 & 1 \\
\hline 5 & Membatik memerlukan modal besar? & 43 & 24 \\
\hline 6 & Jenjang karir tidak jelas? & 10 & 57 \\
\hline 7 & Dapat dilakukan sebagai sambilan? & 49 & 18 \\
\hline 8 & Batik menghabiskan banyak waktu? & 43 & 24 \\
\hline
\end{tabular}

Gambar 1.

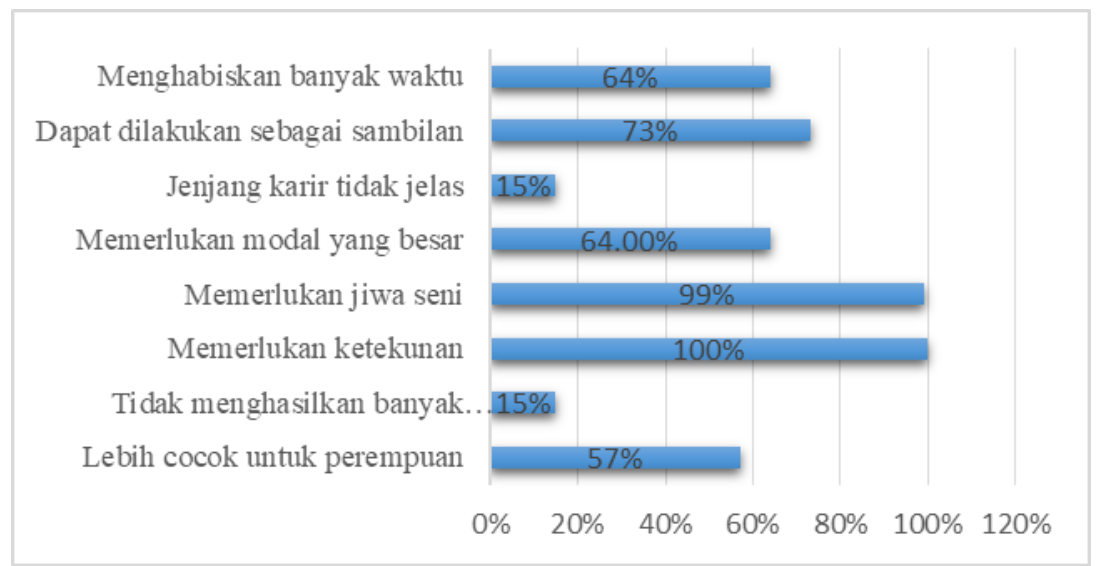

Dari data diatas dapat di lihat bahwa para responden berpandangan untuk menjadi pengerajin batik itu, menghabiskan banyak waktu, dapat dilakukan sebagai sambilan, memerlukan modal yang besar, memerlukan jiwa seni, lebih cocok dilakukan oleh perempuan dan memerlukan ketekunan. Dari data inilah dapat di lihat bagaimana pandangan menganai pengerajin batik di STT Real, maka dapatlah dilihat sejauhmana pendapat para responden mengenai alasan mereka untuk standar untuk mengikuti program ekstrakulikuler batik yang ada.

\section{SIMPULAN}

Pandangan generasi muda adalah sebuah proses kongnitif yang dialami oleh orang yang berusia enambelas sampai tigapuluh tahun didalam memahami informasi tentang lingkungan, baik lewat penglihatan, pendengaran, penghayatan, perasaan,dan penciuman. Sedangkan Pandangan generasi muda terhadap pengerajin batik adalah sebuah proses kongnitif yang dialami oleh orang yang berusia enambelas sampai tigapuluh tahun didalam memahami informasi tentang batik. Dari pandangan atau persepsi seseorang lah yang akan mempengaruhi bagaimana ia bertindak dan hal yang akan dilakukannya. Dari hasil penelitian maka dapat di simpulkan mengenai pandangan generasi muda terhadap pengerajin batik di STT Real Batam bahwa membatik menghabiskan banyak waktu, dapat dilakukan sebagai sambilan, memerlukan modal yang besar, memerlukan jiwa seni, lebih cocok dilakukan oleh perempuan dan memerlukan ketekunan. Dari persepsi inilah yang mempengaruhi mahasiswa untuk terlibat atau tidak mau terlibat dalam mengerajin batik.

UNESCO telah menyatakan batik Indonesia sebagai warisan budaya dunia tak benda, bersama 76 warisan budaya dunia tak benda lainnya. Pengakuan ini juga pada akhirnya menuntut pemerintah dan masyarakat untuk melakukan promosi, pelestarian dan pengembangan. Dengan ini sebagai generasi muda penerus bangsa tentunya harus mengambil peran serta dalam hal ini, dengan kesempatan adanya ekstrakulikuler batik di STT Real tentunya ini menjadi peluang besar dalam peran serta melestarikan budaya bangsa. 
Dengan disimpulkan pandangan para mahasiswa ini maka para pengerajin batik di STT Real dapat memberikan suatu sosialisai yang tepat untuk memberikan pengertian yang benar tentang persepsi yang telah di simpulkan. Hal ini tentunya akan menunjang minat para mahasiswa untuk terlibat dan mengembangkan eksrtakulikuler batik tulis di STT Real Batam.

\section{DAFTAR PUSTAKA}

Kusumawdhani, Reni. How To Wear Batik. Jakarta: PT.Gramedia Pustaka Umum, n.d.

Munawaroh, Siti. Peranan Kebudayaan Daerah Dalam Perwujudan Masyarakat Industri Pariwisata Di Daerah Istimewa Yogyakarta. Yogyakarta: Departement Pendidikan dan Kebudayaan, 1999. S, Deden Dedi. Sejarah Batik Indonesi. Bandung: PT. Sarana Pancakarya Nusa, 2018.

Simarmata, Murni Marlina. Mengenal Batik Nusantara. Jawa Timur: Lestari Kiranatama, 2014.

Suliyanto, Suliyanto, Weni Novandari, and Sri Murni Setyawati. "Persepsi Generasi Muda Terhadap Profesi Pengrajin Batik Tulis Di Perbalingga." Jurnal Ekonomi dan Bisnis 18, no. 1 (2015): 135144.

Sunnara, Rahmat. Legenda Batik Tulis. Buana Cipta Pustaka, 2009. 